\title{
Nitrate Removal from Ground water by Denitrification in Fixed and Fluidized Bed Biofilm Reactors A Comparative Study
}

\begin{abstract}
ION VIOREL PATROESCU*, IOANA ALEXANDRA IONESCU, LUCIAN ALEXANDRU CONSTANTIN, LAURENTIU RAZVAN DINU, VALERIU ROBERT BADESCU

National Research and Development Institute for Industrial Ecology -ECOIND Bucharest, 71-73, Drumul PoduDambovitei, 060652, Bucharest, Romania

The influence of attached biomass bioreactor types on the denitrification process using a low-pitched groundwater containing nitrates was studied. Two types of fixed-bed and fluidized-bed biofilm reactors, equipped with expanded clay granular filler, with a particle size fraction of 2-5 $\mathrm{mm}$ were used. The nitrite and nitrate concentrations in the inflow and outflow of the two bioreactors were analytically determined. Based on the obtained concentration values, the denitrification rates were calculated, ranging between $1275 \div 1387 \mathrm{~g} \mathrm{NO}_{3} \mathrm{~N} / \mathrm{m}^{3} /$ day in the case of the fixed bioreactor and between $3390 \div 3867 \mathrm{~g} \mathrm{NO}_{3}-\mathrm{N} / \mathrm{m}^{3} /$ day in the case of the fluidized bed bioreactor.
\end{abstract}

Keywords: groundwater, denitrification, up-flow biofilm reactor, expanded clay, fixed bed, fluidized bed, nitrate removal rate

AtEuropean level the main potable water sources consist of surface and groundwater [1], the current trend in Romania being a consumption increase due to the extension of water supply to the population [2]. From the treatment process perspective, the raw water quality is very important, depending on the pollution source, being simpler or more complicated [3-5]. Research conducted in Romania [6-9] showed that there are many cases of water sources in which the concentrations of inorganic nitrogen compounds (ammonium, nitrite, nitrate) exceed the imposed legislation values $(0.5 \mathrm{mg} / \mathrm{L}, 50 \mathrm{mg} / \mathrm{L}, 0.1 \mathrm{mg} /$ L) in Europe and Romania [10], [11]. For medical or technological reasons, these compounds should be removed from the water until they reach maximum admissible limits. Although the nitrates toxicity to the human body has notbeen clearly established, it was proved that their presence in water in high concentrations causes methaemoglobinemia in infants younger than 6 months old, and in Romania, research has shown that there is an increased frequency of this disease [12]. Other health problems caused by nitrates are formation of carcinogenic nitrosamines resulting in gastric cancer, birth defects and hypertension. Due to these health problems, nitrates in drinking water should be brought below the imposed standard of $50 \mathrm{mg} / \mathrm{L}$, with the observation that there was an older EU recommendation that this concentration should be $25 \mathrm{mg} / \mathrm{L}$ [13].

Nitrates removal from raw water can be accomplished by various methods: biological processes, ion exchange, reverse osmosis, ultrafiltration, electro dialysis. Among these, only three proved to be feasible on industrial scale: ion exchange, reverse osmosis and biological denitrification. Ion exchange has the disadvantages that there is no resin with a high nitrate selectivity and suitable for solution regeneration. The reverse osmosis disadvantages are that there are no high nitrate selective membranes for the salts concentrate removal. Biological denitrification is a promising method due to its high nitrate selectivity. It can be achieved with almost 100\% efficiency. Nitrates removal by biological denitrification is the process

*email: patroescuv@yahoo.com; Phone: +40749040588 in which microorganisms reduce nitrate to nitrogen gas through the following transformation chain [14]:

$$
\mathrm{NO}_{3} \rightarrow \mathrm{NO}_{2} \rightarrow \mathrm{NO} \rightarrow \mathrm{N}_{2} \mathrm{O} \rightarrow \mathrm{N}_{2}
$$

Autotrophic denitrification occurs when an inorganic carbon substrate is used while heterotrophic denitrification takes place when using an organic carbon substrate methanol, ethanol, acetic acid. In this case the denitrification process can be realized in a fixed or fluidized bed reactor [15-17].

Denitrification rates depend on several factors, the most important being: $\mathrm{pH}$, temperature, $\mathrm{COD}$ and $\mathrm{NO}_{3}-\mathrm{N}$ concentrations in the inflow, reaction time, biofilm growth surface in the reactor. Depending on the operating conditions, in the literature denitrification rates were reported of being in the range of $0.8 \div 1.2 \mathrm{~kg} \mathrm{~N} / \mathrm{m}^{3} /$ day in a fixed bed bioreactor [18] and $0.42 \div 20.70 \mathrm{~kg} \mathrm{~N} / \mathrm{m}^{3} /$ day in a fluidized bed bioreactor [19].

Biological denitrification is not used within Romanian water treatment plants, but there locations for which raw water sources contains nitrates at concentrations exceeding maximum admissible values, especially within rural areas in water wells, drainages and high depth groundwater wells.

\section{Experimental part}

Denitrification experiments were performed in the aim to compare denitrification rates within two bioreactors: with fixed bed biomass and fluidized bed biomass. The inert media used for biofilm's growth was of granular type - light expanded clay.

The following research works were performed in order to achieve the above mentioned objectives:

-characterization of low depth groundwater source in order to determine the values of chemical parameters involved in the biological denitrification step: $\mathrm{pH}, \mathrm{DO}, \mathrm{NH}_{4}^{+}$, $\mathrm{NO}_{2}, \mathrm{NO}_{3} ; \mathrm{PO}_{4}^{3}, \mathrm{DOC}$;

-design and construction of the two pilotscale biological reactors;

-growth of biomass on the inert granular media;

-operation of bioreactors at the suitable values of parameters; 
-analytical investigation of inflow and outflow in order to determine $\mathrm{pH}, \mathrm{DO}, \mathrm{NH}_{4}^{+}, \mathrm{NO}_{2}, \mathrm{NO}_{3}{ }^{-} \mathrm{PO}_{4}{ }^{3-}, \mathrm{DOC}$ concentrations;

-calculation of nitrate removal rate.

\section{Materials and methods}

Biological denitrification experiments were conducted in two continuous pilot scale biofilm reactors operated in up-flow mode (fig. 1) at two different ranges of water flow rate, the one for fixed bed and the other, much bigger, for fluidized bed. The fixed bed biofilm reactor had a diameter of $100 \mathrm{~mm}$ and a bed height of $1.60 \mathrm{~m}$ and fluidized bed biofilm reactor had a diameter of $50 \mathrm{~mm}$ and a bed height before fluidization of $0.80-0.90 \mathrm{~m}$.

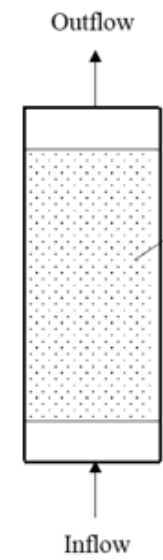

Fixed or

fluidized bedFig. 1. Schematic of up-flow biofilm reactors

The used packed media was the $2 \div 5 \mathrm{~mm}$ particle size fraction of expanded clay aggregates, obtained by sieving from an LaterliteTM Leca commercial assortment (fig. 2)

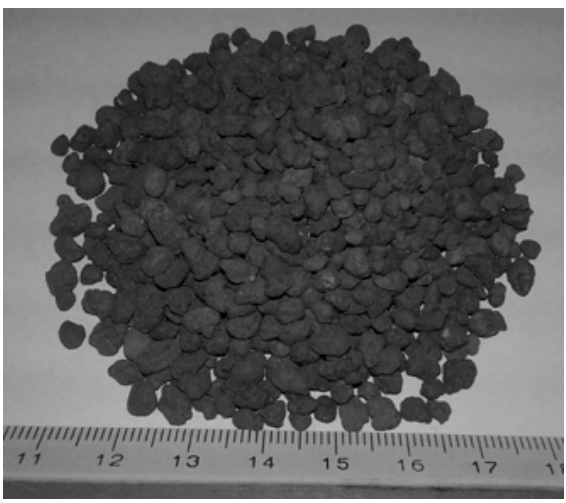

Fig. 2. Expanded clay aggregates, 2-5 $\mathrm{mm}$ particle size fraction

First, the granular media used as packed bed was wetted and inoculated for a month and then the denitrification experiments were conducted for 1-1.5 months at the operating parameters presented in table 1.

The biofilm reactors were washed at parameters which are presented in table 2 . In the case of fluidized bed, the aim of washing was to detach the flocks trapped into fluidized bed.
In the fixed bed bioreactor case, the trapped nitrogen gas removal was carried out daily, by increasing the water flow rate within the reactor to values of $20-25 \mathrm{~m} / \mathrm{h}$.

The denitrification processes performed in the two biofilm reactors were investigated by analytical methods that determined nitrate $\left(\mathrm{NO}_{3}^{-}\right)$, nitrite $\left(\mathrm{NO}_{2}{ }^{-}\right)$and ammonium $\left(\mathrm{NH}_{4}^{+}\right)$concentrations both in the inflows and outflows. Concentrations of previously mentioned inorganic nitrogen forms, as well as the phosphate ion ( $\mathrm{PO}_{4}^{3-}$ ) concentration were determined by ion chromatography using an ICS-3000 system (Dionex, USA), according to standard method SR EN ISO 14911 for ammonium, and SR EN ISO 10304/1:2009 for anions. Other parameters that were investigated: concentration of dissolved organic carbon (DOC) was measured according to standard method SR EN 1484:2001 with a N/C 3100 analyzer (Analitik Jena, Germany), dissolved oxygen (DO) concentration was measured with Oxi320 device (WTW, Germany); $p \mathrm{H}$ and temperature were measured with $\mathrm{C} 932$ device (Consort, Belgium).

Microscopic investigations were performed using a scanning electron microscope, Quanta FEG 250 model (FEI, USA).

\section{Results and discussions \\ Filling characteristics determination}

In order to be used as a growth medium for the heterotrophic nitrifying biomass, $2 \div 5 \mathrm{~mm}$ of light expanded clay granulometric fraction was used in experimental works. The characteristics that are influencing the denitrification process, such as porosity, surface morphology and the layer expandability depending on the water flow rate within the column were determined.

The main characteristics of this media are shown in table 3. The grain surface is like the one presented in figure 3 as Scanning Electronic Microscopy (SEM) micro-photo and the dependence between fluidized bed expanding and water flow rate is the one presented in figure 4.

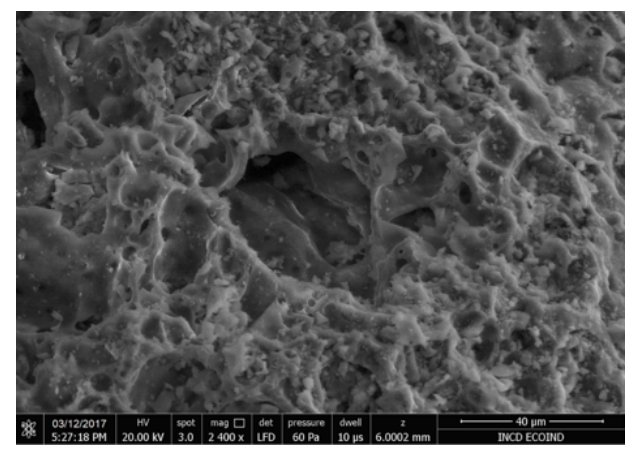

Fig. 3. SEM image of light expanded clay aggregate surface

\begin{tabular}{|c|c|c|c|c|}
\hline $\begin{array}{c}\text { Type of up-flow } \\
\text { biofilm reactor }\end{array}$ & $\begin{array}{c}\text { Average } \\
\text { temperature in } \\
\text { reactor, }\left[{ }^{\circ} \mathbf{C}\right]\end{array}$ & $\begin{array}{c}\text { Contact time, } \\
{[\text { min.] }}\end{array}$ & $\begin{array}{c}\text { Water flow rate, } \\
{[\mathbf{m} / \mathbf{h}]}\end{array}$ & $\begin{array}{c}\text { Expanding of fluidized bed, } \\
\mathbf{E}=\mathbf{l}-\mathrm{H}_{0} / \mathrm{H}\end{array}$ \\
\hline Fixed bed & $13.8 \div 16.4$ & $3.8 \div 4.3$ & $10.2 \div 11.5$ & 0 \\
\hline Fluidized bed & $14.2 \div 17.8$ & $1.1 \div 1.2$ & $57.6 \div 58.6$ & $0.28 \div 0.30$ \\
\hline
\end{tabular}

\begin{tabular}{|c|c|c|c|c|c|}
\hline $\begin{array}{l}\text { Type of up-flow } \\
\text { biofilm reactor }\end{array}$ & Frequency & $\begin{array}{c}\text { Washing time, } \\
\text { [min] }\end{array}$ & $\begin{array}{c}\text { Air flow rate, } \\
{[\mathrm{m} / \mathrm{h}]}\end{array}$ & $\begin{array}{l}\text { Water flow } \\
\text { rate, }[\mathrm{m} / \mathrm{h}]\end{array}$ & $\begin{array}{c}\text { Table } 2 \\
\text { WASHING PARAMETERS FOR UP-FLOW }\end{array}$ \\
\hline Fixed bed & Once $/ 2$ days & 10 & 60 & 25 & BIOFILM REACTORS \\
\hline Fluidized bed & Once/week & 1 & 60 & - & \\
\hline
\end{tabular}

\begin{tabular}{|c|c|c|c|c|}
\hline Particle size fraction, [mm] & $\begin{array}{c}\text { Dl0 } \\
\text { diameter } \\
{[\mathrm{mm}]}\end{array}$ & $\begin{array}{c}\text { Material } \\
\text { density, } \\
{\left[\mathrm{kg} / \mathrm{m}^{3}\right]}\end{array}$ & $\begin{array}{c}\text { Bulk density, } \\
{\left[\mathrm{kg} / \mathrm{m}^{3}\right]}\end{array}$ & $\begin{array}{c}\text { Porosity, } \\
{[\%]}\end{array}$ \\
\hline $2-5$ & 2.3 & 815 & 440 & 46 \\
\hline
\end{tabular}

Table 3

CHARACTERISTICS OF LECA LATERLITE ${ }^{\text {TM MEDIA }}$ 


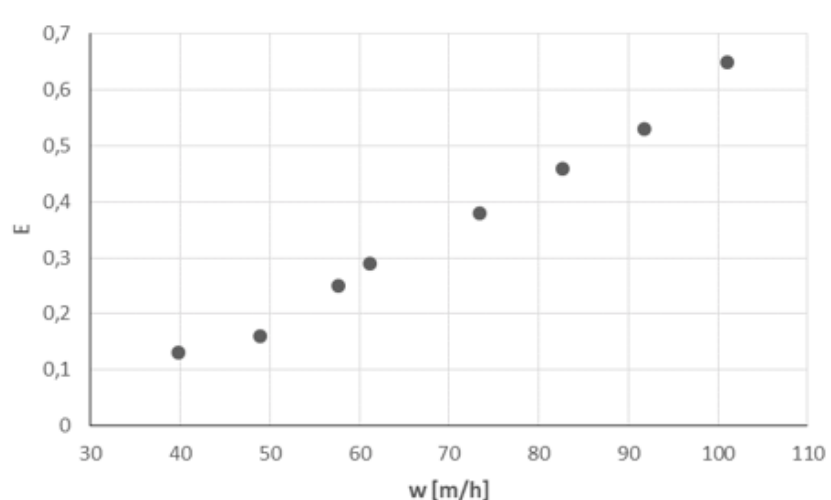

Fig. 4. Expanding of fluidized bed formed from light expanded clay aggregates, 2-5 $\mathrm{mm}$ particle size fraction vs. the water flow rate in column

Inflow and outflow quality assessment

The inflows of the two denitrification pilot scale bioreactors consisted of low-pitched underground raw water, enriched with ethanol used as a carbon source for heterotrophic denitrifying biomass growth. Analytical determinations for inflow and outflow characterization revealed the concentration ranges shown in table 4 and table 5.

Table 4

CHARACTERISTICS OF BIOFILM REACTOR INFLOWS

\begin{tabular}{|c|c|c|c|}
\hline Parameter & Measurement unit & Fixed bed & Fluidized bed \\
\hline $\mathrm{pH}$ & - & $6.58-6.96$ & $6.56-6.60$ \\
\hline $\mathrm{DO}$ & $\mathrm{mg} / \mathrm{L}$ & $0.2-0.3$ & $0.2-0.3$ \\
\hline $\mathrm{NH}_{4}{ }^{+}$ & $\mathrm{mg} / \mathrm{L}$ & $1.7-2.4$ & $1.7-2.1$ \\
\hline $\mathrm{NO}_{3}^{-}$ & $\mathrm{mg} / \mathrm{L}$ & $38.9-41.9$ & $36.1-39.5$ \\
\hline $\mathrm{NO}_{2}^{-}$ & $\mathrm{mg} / \mathrm{L}$ & $<0.1$ & $<0.1$ \\
\hline $\mathrm{PO}_{4}{ }^{--}$ & $\mathrm{mg} / \mathrm{L}$ & $0.4-0.7$ & $0.4-0.7$ \\
\hline $\mathrm{DOC}$ & $\mathrm{mg} / \mathrm{L}$ & $12.2-21.5$ & $9.2-13.6$ \\
\hline
\end{tabular}

Table 5

CHARACTERISTICS OF BIOFILM REACTOR OUTFLOWS

\begin{tabular}{|c|c|c|c|}
\hline Parameter & Measurement unit & Fixed bed & Fluidized bed \\
\hline $\mathrm{pH}$ & - & $6.84-7.07$ & $6.77-6.90$ \\
\hline $\mathrm{NH}_{4}{ }^{+}$ & $\mathrm{mg} / \mathrm{L}$ & $0.5-0.9$ & $1.7-1.9$ \\
\hline $\mathrm{NO}_{3}{ }^{-}$ & $\mathrm{mg} / \mathrm{L}$ & $1.1-5.2$ & $24.9-26.5$ \\
\hline $\mathrm{NO}_{2}{ }^{-}$ & $\mathrm{mg} / \mathrm{L}$ & $0.1-1.6$ & $1.1-3.6$ \\
\hline $\mathrm{DOC}$ & $\mathrm{mg} / \mathrm{L}$ & $6.6-14.5$ & $6.4-12.5$ \\
\hline
\end{tabular}

\section{Denitrification process -visual monitoring} monitored daily. The presence of gaseous nitrogen bubbles at the top of the fluidized bed bioreactor (fig. 5) and at the top of the fixed bed bioreactor during degassing operation, were visual monitored. Also, the periodic microscopic examination of expanded clay granules, extracted from the reactors, revealed the presence of compact denitrifying heterotroph biofilm plates on their surface (fig. 6).

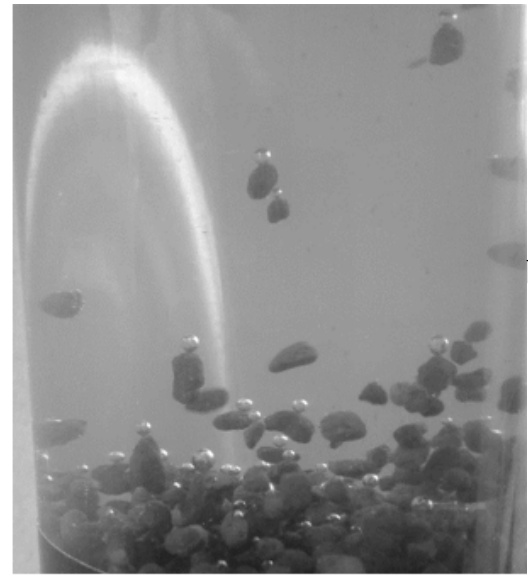

Fig.5. Grains of light expanded clay with attached nitrogen gas bubbles at the upper side of the fluidized bed biofilm reactor
The denitrification processes in the two bioreactors was

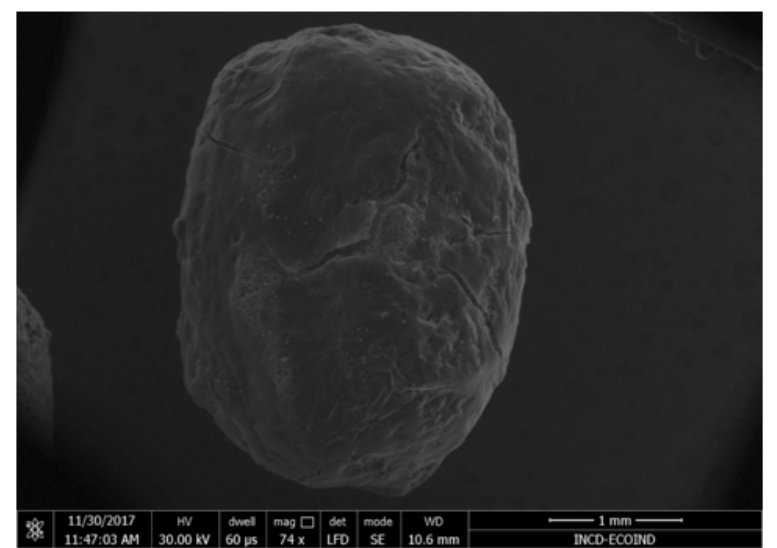

Fig. 6. SEM image of a light expanded clay aggregate covered with denitrifying biofilm

\section{Calculation of nitrate removal rate}

Nitrate removal rate was calculated according to the following equation:

$$
V_{D N}=\frac{Q_{\text {in }}\left(S_{\text {in }}-S_{\text {out }}\right)}{V_{b}}
$$

where:

$\mathrm{V}_{\mathrm{DN}}$ - nitrate removal rate, $\mathrm{g} \mathrm{NO}_{3}-\mathrm{N} / \mathrm{m}^{3} /$ day;

$\mathrm{Q}_{\text {in }}$ - inflow flowrate, $\mathrm{m}^{3} / \mathrm{day}$;

$\mathrm{S}_{\text {in }}$ - inflow $\mathrm{NO}_{3}-\mathrm{N}$ concentration, $\mathrm{mg} / \mathrm{L}$;

$\mathrm{S}_{\text {out }}$ - pseudo steady state outflow $\mathrm{NO}_{3}-\mathrm{N}$ concentration and $\mathrm{NO}_{2}-\mathrm{N}$ concentration sum for each loading condition, $\mathrm{mg} / \mathrm{L}$;

$\mathrm{V}_{\mathrm{b}}$ - volume of fixed bed, $\mathrm{m}^{3}$.

The nitrate removal rates, calculated according to the formula (2), for each of the two types of bioreactors were in the range $1275 \div 1387 \mathrm{~g} \mathrm{NO}_{3}-\mathrm{N} / \mathrm{m}^{3} /$ day for the fixed bed bioreactor and in the range of $3390 \div 3867 \mathrm{~g} \mathrm{NO}_{3}-\mathrm{N} / \mathrm{m}^{3} /$ day for the fluidized bed bioreactor (fig. 7).

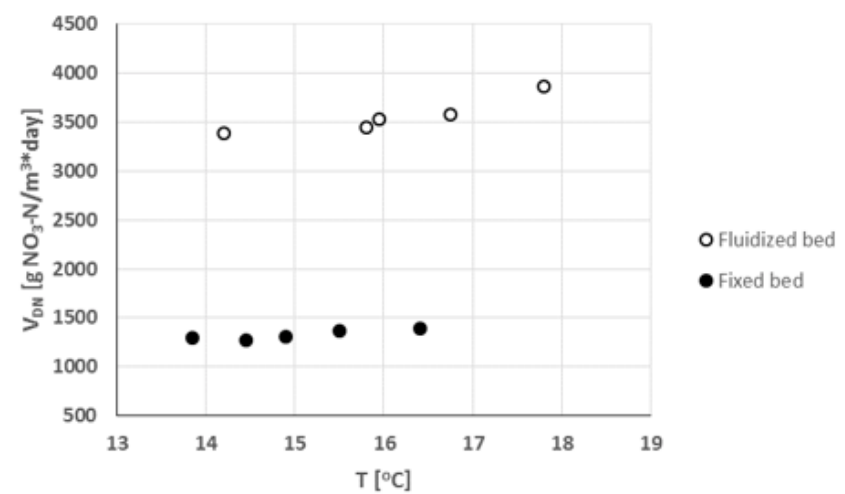

Fig. 7. Denitrification rates in fixed and fluidized bed biofilm reactors using the $2-5 \mathrm{~mm}$ particle size fraction of light expanded clay aggregates as granular packed bed

\section{Conclusions}

The obtained denitrification rates in the fixed bed bioreactor reactor ranged from 1275 to $1387 \mathrm{~g} \mathrm{NO}_{3}-\mathrm{N} / \mathrm{m}^{3} /$ day under the following operating parameters: temperature $=13.8 \div 16.4^{\circ} \mathrm{C}$, contact time $=3.8 \div 4.3 \mathrm{~min}$, flow rate $=10.2 \div 11.5 \mathrm{~m} / \mathrm{h}$. The residual nitrite and nitrate concentrations in the fixed bed bioreactor outflow were between $1.1 \div 5.2 \mathrm{mg} \mathrm{NO}_{3}^{-} / \mathrm{L}$ and $0.1 \div 1.6 \mathrm{mg} \mathrm{NO}_{2}-1 \mathrm{~L}$. The nitrate values were higher than the maximum admissible limit $\left(0.1 \mathrm{mg} \mathrm{NO}_{2}^{-} / \mathrm{L}\right)$, for a inflow with $38.9 \div 41.9 \mathrm{mg} \mathrm{NO}_{3}^{-}$ /L content.

The obtained denitrification rates in the fluidized bed bioreactor ranged from 3390 to $3867 \mathrm{~g} \mathrm{NO}_{3}-\mathrm{N} / \mathrm{m}^{3} /$ day under 
the following operating parameters: temperature $=$ $14.2 \div 17.8^{\circ} \mathrm{C}$, contact time $=1.1 \div 1.2 \mathrm{~min}$, flow rate $=$ $57.6 \div 58.6 \mathrm{~m} / \mathrm{h}$. The residual nitrite and nitrate concentrations in the fluidized bed bioreactor outflow were $24.9 \div 26.5 \mathrm{mg} \mathrm{NO}_{3}^{-} / \mathrm{L}$ and $1.1 \div 3.6 \mathrm{mg} \mathrm{NO}_{2} / \mathrm{L}$. The nitrate values were higher than the maximum admissible limit $\left(0.1 \mathrm{mg} \mathrm{NO}_{2}^{-} / \mathrm{L}\right)$, for an inflow with $38.1 \div 39.5 \mathrm{mg} \mathrm{NO}_{3}^{-} / \mathrm{L}$ content.

By increasing the water - biofilm contact time the residual nitrate and nitrite concentrations can be reduced, even below the maximum admissible limit in nitrite case. In the fix bed bioreactor case this can be achieved by increasing the filling layer height or by reducing water flow rate within the column. In the fluidized bed bioreactor case the same results can be achieved increasing the filling layer height or by partly recirculating the outflow.

The denitrification rates obtained in the fluidized bed bioreactor are 2.5 times higher than those obtained in the fixed bed bioreactor. This can be explained by the intensification of the substrate transfer processes that occur in the developed biofilm by using the fluidized bed technique. The main result is a reduced reaction volume. The drawback is represented by an additional energy consumption. A decision in choosing a bioreactor type can only be made after a technical economic calculation, taking into account both the investment and operating costs.

Acknowledgments: This study has been carried out within the framework of the Nucleu Programme (Environmental Research Priority in Sustainable Industrial Development based on Knowledge and Innovation -ECO-MEDIND, PN 16-250305 project).

\section{References}

1. Van der HOEK, J.P., BERTELKAMP, C., VERLIEFDE, A.R.D., SINGHAL, N., Journal of Water Supply: Research and Technology - AQUA, 63, no. 2, 2014, p. 124.

2. ANGHELUTA, P.S., RADULESCU, C.V., International Symposium The Environment and the Industry, Proceedings Book, 2017, p. 330.
3. STEFANESCU, M., CRISTEA, I., COSMA, C., International Symposium The Environment and the Industry, Proceedings Book, 2017, p.16.

4. PATROESCU, I.V., DINU, L.R., CONSTANTIN, L.A., ALEXIE, M., JINESCU, G., Rev. Chim. (Bucharest), 67, no. 8, 2016, p. 1433.

5. CuCIUREANU, A., KIM, L., LEHR B. C., ENE, C., Rev. Chim. (Bucharest), 68, no. 8, 2017, p. 1695.

6. DIRTU, D., PANCU, M., MINEA, M.L., DIRTU, A.C., SANDU, I., Rev. Chim. (Bucharest), 67, no. 10, 2016, p. 2059.

7. ADUMITROAEI, M.V., GAVRILOAIEI, T., SANDU, A.V., IANCU, G. 0., Rev. Chim. (Bucharest), 67, no. 12, 2016, p. 2530.

8. ICHINUR, O., Rev. Chim. (Bucharest), 67, no. 12, 2016, p. 2405.

9. CIRTINA, D., CAPATINA, C., Rev. Chim. (Bucharest), 68, no. 2, 2017, p. 221.

10.*** European Community, Directive of November 1998 relating to the quality of water intended for human consumption. 98/83/EEC. Off. J. Eur. Commun. 32. L330.

11. *** PARLAMENTUL ROMANIEl, Legea nr. 458/2002 (republicata) privind calitatea apei potabile, Monitorul Oficial nr. 875/2011, 2011.

12. TARCEA, M., BACAREA, A., FULOP, E., RUTA, F., COMANEANU, R.M., HANCU, V., ORMENISAN, A., Rev. Chim. (Bucharest), 67, no. 12, 2016, p. 2556.

13. *** European Community, Directive of July 1980 relating to the quality of water intended for human consumption. 80/778/EEC. Off. J. Eur. Commun. 23. L229.

14. SRINU NAIK, S., PYDI SETTY, Y., International Conference on Chemical, Environmental Science and Engineering (ICEEBS'2012), Proceedings, 2012, p. 47.

15. SOARES, M.I.M., Water, Air and Soil Pollution, 123, 2000, p. 183.

16. ZOU, G., PAPIRIO, S., LAKANIEMI, A-M., AHORANTA, S.H., PUHAKKA, J.A., Chem. Eng. J., 284, 2016, p. 1287.

17. PRASANNA LAKSHMI, L., PYDI SETTY, Y, VIMALA, K., The $13^{\text {th }}$ International Conference on Fluidization - New Paradigm in Fluidization Engineering, Proceedings, 2010, p.1

18. ROGALLA, F., RAVARINI, P., De LARMINAT, G., COUTTELLE, J., IWEM 89 Conference, Proceedings, 1990, p. 319.

19. BURGHATE, S.P., INGOLEN.W., Int. Res. J. Environment Sci., 2, no. 12,2013, p. 42.

$\overline{\text { Manuscript received: } 12.08 .2018}$ 